\title{
Complex Compost and Detoxification of Heavy Metals in Chernozem
}

\section{Ivan S Belyuchenko*}

Kuban State Agrarian University Kalinin, Krasnodar, Russian Federation

\section{Detoxification of Soils}

The detoxification basis of soil is a complex compost (organic and mineral mixtures). Important element of a detoxication of soils is ability of cations of heavy metals in complex compost to form insoluble connections of specific adsorption of clay substances and separate disperse systems on different substrata differing maintenance of a humus, calcium and concentration of $\mathrm{pH}$ (first of all chernozem soil). For example, washing away of $\mathrm{Zn}$ in complex composts at the level of $0.005 \mathrm{mg}-\mathrm{eq} / 100 \mathrm{~g}$ indicates great value in vertical migration of heavy metals.

Plants are an important factor in the movement of heavy metals, the root system of plants keeps a large number of ions due to the interaction of morphological structures and chemical reactions, nonspecific nature (exchange capacity of roots, the salt concentration in the vacuoles, chemical inactivation of the individual compounds, and so on). Entering into the soil of complex compost with the saved-up heavy metals causes increased protection mechanisms and strengthening antagonists' ions in plants. For example, increase in the upper layer of soil the maximum allowable concentration of $\mathrm{Co}, \mathrm{Cd}, \mathrm{Cu}, \mathrm{Pb}$, Ni doesn't reduce a harvest of sugar beet, but contributes to the phosphorus and potassium in roots crops. The type and composition of pollutants in the soil at introduction of complex compost is an important factor at assessment of stability of plants to heavy metals because interaction of heavy metals can have a synergistic and antagonistic character. The variability of the interaction between heavy metals is determined by the synergy of $\mathrm{Cd}-\mathrm{Pb}, \mathrm{Ni}$ and $\mathrm{Co}-\mathrm{Cu}$. This may be an artifact arising from the destruction of the physiological barrier in organisms stress due to excessive interaction of heavy metals. The interaction of elements and their antagonism or synergism is influence by the components of the system soil-plant.

The imbalance of the system soil-plant influences pollution of plants and decrease in their productivity. The introduction of complex compost establishes balance in system and buffer capacity of soils. Buffer action of soils determined by organic matter and clay complex, chemical, electric, ion-exchange, oxidation-reduction, acid or alkaline and sorption properties which change under the influence of heavy metals and alter the habitat of plants and animals.

The buffer capacity of soils is defined by chemical properties of pollutants (mobility, ability to enter ionic exchange, to be fixed in soil colloids at a hemosorbtion, a complex formation and sedimentation). Concentration of any solution and resistance to pollution of complex composts depend on the content in complex composts of fine materials, their amount and quality, organic matter and level of their acidity or alkalinity. Processes of sedimentation, dissolution and distribution of heavy metals between a firm phase in complex compost vary in wide limits.

Acid-base properties of individual metals define a form of their compounds, the magnitude and sign of the charge of the particle (a cation, an anion, a neutron) in complex compost, durability of communication and quantity of the withheld particles. Ion-exchange absorption of cationic forms in complex compost (metals, non-metals) increases at the lowered acidity, and at anion forms inverse relationship
- the main part of anion forms is sorbed in the alkalescent environment with prevalence of anions in a two-charging form, for example the maximum of mercury keeps at $\mathrm{pH}$ 4.8-6.5.

Moisture, neutral reaction complex compost and humus stability limit the mobility of heavy metals in the upper horizon of the steppe zone. At carbonate accumulation precipitation enriched with strontium and barium collects, but $\mathrm{B}, \mathrm{Ag}, \mathrm{Mo}, \mathrm{V}$, As are mobile in the form of true solutions in all complex compost. Usually movements of all elements in complex compost slow and at evaporation $\mathrm{Ag}, \mathrm{Hg}, \mathrm{B}, \mathrm{Mo}$ accumulate; $\mathrm{Mn}, \mathrm{Fe}, \mathrm{Cu}, \mathrm{Mo}$ are mobile in difficult complexes with organic and mineral substances; at alkaline reaction in colloidal state many elements actively move in the form of simple salts.

Capability of complex compost to inactivate heavy metals it is connected with the magnitude of the actual acidity, high content of a humus and clay. Buffer action of complex compost depends on the capacity of cationic exchange (integral characteristic of humus, clay and actual acidity ordinary chernozem soil).

\section{Way of Cleaning of Chernozem Soils of Heavy Metals with Use of Complex Composts}

Researches were conducted on the site which is strongly polluted by heavy metals, earlier occupied with an orchard.

Technical result is simplification and reducing process, labor costs and energy consumption reduction, increase in efficiency of cleaning of the chernozem polluted by heavy metals by connecting their mobile forms of organomineral complexes that are unavailable to plants.

The way of cleaning of the chernozem soils polluted by heavy metals includes use of the inducing substance in the form of complex compost. This complex compost consists of mix of a phosphite, single superphosphate and semi-rerotting manure of cattle at a certain ratio depending on the level of concentration of alkaline metals, (w/w, \%): phosphite - 7.0-8.0; single superphosphate - $0.8-1.0$; semi-rerotting manure of cattle - 50-60 t/ha. The complex compost with organic matter content to $20 \%$ and $\mathrm{pH}$ is $6.0-6.5$ is introduced into the soil once in 5-6 years at a dose of 70-75 $\mathrm{t} / \mathrm{ha}$. This complex compost capable to reduce alkalinity of the main chernozems from $\mathrm{pH} 8.4$ to 7.2-7.5. Depth of processing of the soil to $18-20 \mathrm{~cm}$.

Uniqueness of this way is that the used complex compost in a year significantly reduces the maintenance of mobile forms of heavy metals

*Corresponding author: Ivan S Belyuchenko, Kuban State Agrarian University Kalinin St. 13, Krasnodar, Russian Federation, Tel: +78612215942; E-mail: bioeco@inbox.ru

Received October 25, 2016; Accepted November 02, 2016; Published November 15,2016

Citation: Belyuchenko IS (2016) Complex Compost and Detoxification of Heavy Metals in Chernozem. J Environ Anal Toxicol 6: 417. doi: 10.4172/21610525.1000417

Copyright: @ 2016 Belyuchenko IS. This is an open-access article distributed under the terms of the Creative Commons Attribution License, which permits unrestricted use, distribution, and reproduction in any medium, provided the original author and source are credited. 
(Co, $\mathrm{Mn}, \mathrm{Cu}, \mathrm{Cd}, \mathrm{Ni}, \mathrm{Pb}, \mathrm{Zn}$ ) by $60-70 \%$. Use of complex compost at the specified ratio of his components re duces mobility of many heavy metals by preservation them in organic-mineral complex [1-3].

Entering the soil of complex compost significantly increases the content of organic substance and reduces alkalinity. It is an important condition of transition of heavy metals to remote connections for plants. The positive result is achieved in case of a combination in complex compost specified by a sign and reduces intake of heavy metals in agricultural products.

As a part of complex compost the maintenance of a phosphite has increased from 10 to $15 \%(\mathrm{w} / \mathrm{w}$ ) because of higher $\mathrm{pH}$ of the chernozem ordinary (from 7.8-8.2 to 9.0-9.2). At concentration of a phosphite more $15 \%$ of $\mathrm{pH}$ in complex compost decreases less than 6.0. It leads to increase in acidity recultivated the soil and increases mobility of heavy metals. The concentration of a phosphite less than $10 \%(\mathrm{w} / \mathrm{w})$ is insufficient for formation of $\mathrm{pH}$ 6.0-6.5 compost. The use of complex compost of $0.8-1.0 \%$ of superphosphate simple enriches recultivated soil phosphorus and binds the nitrogen. If in a complex compost of superphosphate simple concentration of less than $0.8 \%(\mathrm{w} / \mathrm{w})$, it is not enough to ensure soil and plant phosphorus, at superphosphate of $1.0 \%$ $(\mathrm{w} / \mathrm{w})$ the soil is provided by phosphorus.

These researches were conducted by department of the general biology and ecology in JSC "Zavety Ilyicha" of the Leningrad district. The complex compost was brought on the area of 2 hectares, decrease in the maximum allowable concentration level of mobile forms of heavy metals $(\mathrm{Pb}, \mathrm{Cd}, \mathrm{Ni})$ in the soil was a research objective. Before use of complex compost in the soil the content of organic substance is 3,5\% and $\mathrm{pH}$ 7.8-8.2. Gross content of lead - 70,2 (2.19 MAC), cadmium
-1.22 (2.44 MAC), nickel - 188,9 mg/kg (2.22 MAC), mobile forms of heavy metals - 13,6 (2.27 MAC); 0.21 (2.10 MAC); 9.4(2.35 MAC). A year after use of complex compost in a dose of 70-75 $\mathrm{t} / \mathrm{ha}$ the gross content of heavy metals in the soil has increased: lead - 78.5, cadmium - 1.26, nickel - $200.4 \mathrm{mg} / \mathrm{kg}$; the maintenance of mobile forms has reduced up to $4.5 \mathrm{mg} / \mathrm{kg}$ (0.75 MAC); $0.05 \mathrm{mg} / \mathrm{kg}$ (0.50 MAC); $2.4 \mathrm{mg} /$ $\mathrm{kg}(0.60 \mathrm{MAC})$.

In 5 years after use of complex compost the gross maintenance of mobile forms has increased: lead - $5.4 \mathrm{mg} / \mathrm{kg}(0.90 \mathrm{MAC})$ cadmium - 0.08 $\mathrm{mg} / \mathrm{kg}$ (0.80 MAC), nickel - $3.6 \mathrm{mg} / \mathrm{kg}$ (0.90 MAC). For maintenance in the soil of the lowered maximum allowable concentration level in 5 years it is necessary to reuse complex compost. As a result of carrying out experience the content of organic substance in the soil polluted by heavy metals has increased to $3.9 \%$, and $\mathrm{pH}$ has decreased to 7.2-7.5. it promotes binding of mobile forms of heavy metals in connections, inaccessible for plants $[4,5]$.

\section{References}

1. Belyuchenko IS (2014) Wastes of different production and their properties in Ciencia e Tecnica Vitivinicola. Printed in Portugal 29: 37-50.

2. Belyuchenko IS (2014) Complex compost and soil protection from heavy metals in the agrolandscape system. Bothalia Journal 44: 69-79.

3. Belyuchenko IS (2016) Cultivated Lands of Kuban and Features of their Development. International Journal of Environmental and Science Education 11: $6255-6276$

4. Belyuchenko IS (2015) Living organisms in household and production wastes as functional basis compound compost formation. Ecology, Environment and Conservation Paper 21: 47-56.

5. Belyuchenko IS (2016) The Role of Complex Compost in Remediation of Soils in Cultivated Lands. International Journal of Applied Environmental Sciences 11: $1007-1023$. 